\title{
P02-029 - CAPS or SJIA
}

\author{
E Alekseeva, R Denisova*, S Valieva, T Bzarova, T Sleptsova, E Mitenko, K Isayeva \\ From 7th Congress of International Society of Systemic Auto-Inflammatory Diseases (ISSAID) \\ Lausanne, Switerland. 22-26 May 2013
}

\section{Introduction}

Systemic Juvenile Idiopathic Arthritis (sJIA) is chronic disease. Some patients are resistant to standard immunosupressivetherapy and anti IL6 treatment. Some of these patients have autoinflammatory disease.

\section{Case Report}

The patient became ill when she was 3 years old. She had fever, rash and artralgia and pericarditis. After examination in hospital she was diagnosed sJIA. She took glucocorticosteroids $1 \mathrm{mg} / \mathrm{kg}$ daily per os, methylprednisolone $10 \mathrm{mg} / \mathrm{kg}$ IV, №3, and MTX $10 \mathrm{mg} / \mathrm{m} 2 /$ week with positive results. She took that therapy during 2 years. When the dose of GC decreased she had flares (fever, rash, arthritis). In 2 years after beginning she was examined for TRAPS. She took infliximab without improving. The analysis for TRAPS was negative. When she took GC $0,5 \mathrm{mg} / \mathrm{kg} /$ day she had sever flare and tocilizumab treatment was initiated. The fever disappeared and CRP was normal but rash was persisted. She took tocilizumab 10 months and dose of GC was decreased to $0,05 \mathrm{mg} / \mathrm{kg} /$ day. After 10 months of tocilizumab treatment she had toxic allergic reaction and tocilizumab was canceled. She was examined for CAPS and mutation in gene NLRP3 - c.2113C $>$ A in geterozygota. In that time there was no anti IL-1 medicines in Russia so she was given cyclosporine and MTX was continued. When she was 7 years old for flare canacinumab therapy was initiated in dose $4 \mathrm{mg} / \mathrm{kg}$. The fever, rash, arthritis were disappeared and CRP and ESR became normal. After 3 months GC was cancelled. After 4 canacinumab injection she had flare and puls therapy of GC IV was performed with positive results.

\section{Discussion}

So it is still question if she has CAPS or sJIA. Because She is not in remission on anti IL 1 therapy and also GC

Rheumatology, Scientific Center Of Children's Health of RAMS, Moscow, Russian Federation therapy is effective for this patient and on the other hand she has mutation in the cryopirin gene.

\section{Disclosure of interest}

None declared.

Published: 8 November 2013

doi:10.1186/1546-0096-11-S1-A136

Cite this article as: Alekseeva et al:: P02-029 - CAPS or SJIA. Pediatric

Rheumatology 2013 11(Suppl 1):A136.
Submit your next manuscript to BioMed Central and take full advantage of:

- Convenient online submission

- Thorough peer review

- No space constraints or color figure charges

- Immediate publication on acceptance

- Inclusion in PubMed, CAS, Scopus and Google Scholar

- Research which is freely available for redistribution
() Bïomed Central
C Biomed Central

C 2013 Alekseeva et al; licensee BioMed Central Ltd. This is an Open Access article distributed under the terms of the Creative Commons Attribution License (http://creativecommons.org/licenses/by/2.0), which permits unrestricted use, distribution, and reproduction in any medium, provided the original work is properly cited. 